\title{
Reaction of ketene and [dimethyl(phenyl)silyl]ketene with the aminoxyl radical TEMPO: preparative, kinetic, and theoretical studies of unreactive ketenes
}

\author{
Annette D. Allen, Huda Henry-Riyad, and Thomas T. Tidwell* \\ Department of Chemistry, University of Toronto, Toronto, Ontario, M5S 3H6 Canada \\ E-mail: ttidwell@chem.utoronto.ca
}

Dedicated to Joseph Muchowski on the occasion of his $65^{\text {th }}$ birthday, and in recognition of his achievements in heterocyclic chemistry in Canada, Mexico, and the United States

(received 01 Nov 02; accepted 29 May 03; published on the web 06 Jun 03)

\begin{abstract}
Ketenes $\mathrm{CH}_{2}=\mathrm{C}=\mathrm{O}$ (1) and $\mathrm{PhMe}_{2} \mathrm{SiCH}=\mathrm{C}=\mathrm{O}$ (12) react with tetramethylpiperidinyloxyl (TEMPO, TO $)$ forming the products $\mathrm{RCH}(\mathrm{OT}) \mathrm{CO}_{2} \mathrm{~T}$ resulting from addition of one TEMPO radical to the carbonyl carbon and a second to the resulting radical. The rate constants estimated for TEMPO addition are the lowest so far determined for addition to ketenes, and together with previous results give a qualitative correlation of $\log k_{2}$ (TEMPO) $=1.20 \log k\left(\mathrm{H}_{2} \mathrm{O}\right)-4.45, r=$ 0.94 for the rate constants for hydration and for TEMPO reaction of the same ketenes. Computations using DFT methods for the reactions of $\mathrm{CH}_{2}=\mathrm{C}=\mathrm{O}$ (1) and $\mathrm{H}_{3} \mathrm{SiCH}=\mathrm{C}=\mathrm{O}$ with aminoxyl radicals are in agreement with the observed relative reactivities and selectivities.
\end{abstract}

Keywords: Ketenes, TEMPO, aminoxyl radicals, reactivity correlation

\section{Introduction}

Previous studies in our laboratory have examined the reactivities of representative ketenes with $\mathrm{H}_{2} \mathrm{O},{ }^{1}$ amines, ${ }^{2}$ and the aminoxyl radical tetramethylpiperidinyloxyl (TEMPO, TO•). ${ }^{3}$ Very wide ranges of reactivity have been observed, with some parallels between the comparative rate constants of ketenes with $\mathrm{H}_{2} \mathrm{O}$ as compared to amines. Rather surprisingly a semi-quantitative empirical correlation between the reactivities with water and TEMPO has been found as shown in eq. $1 .^{3 \mathrm{~d}, \mathrm{f}}$

$$
\log k_{2}(\text { TEMPO })=1.10 \log k\left(\mathrm{H}_{2} \mathrm{O}\right)-3.79
$$


Free radical additions of $\mathrm{H} \bullet, \mathrm{CH}_{3} \bullet, \mathrm{HO} \bullet, \mathrm{F} \bullet, \mathrm{Cl} \bullet$, and $\mathrm{SiH}_{3} \bullet$ to ketene (1) are predicted by molecular orbital calculations to be highly exothermic. ${ }^{3 a}$ Our earlier calculations for the stabilized aminoxyl radical $\mathrm{H}_{2} \mathrm{NO}$ - using DFT methods indicated that attack at the carbonyl carbon forming $\mathbf{2}$ is exothermic, while attack at $\mathrm{CH}_{2}$ forming $\mathbf{3}$ is endothermic, and less favored than attack at 1-C (carbonyl carbon atom) by approximately $25 \mathrm{kcal} / \mathrm{mol}$ (Scheme 1). ${ }^{3 \mathrm{~b}}$

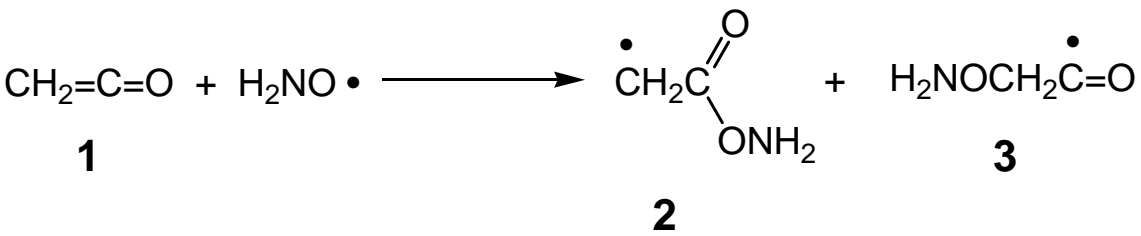

\section{Scheme 1}

This prediction has been tested experimentally using tetramethylpiperidinyloxyl (TEMPO, TO•) with a variety of ketenes, ${ }^{3 \mathrm{~b}-\mathrm{h}}$ and as illustrated with phenylketene reaction occurs readily, with initial in-plane attack of TEMPO at the carbonyl carbon forming an $\alpha$-acyl radical 4 which reacts further with a second TEMPO, forming a diaddition product (Scheme 2). With alkenyl, allenyl, and alkynylketenes allylic or propargylic rearrangement may occur. ${ }^{3 c, e-g}$ Further computations of reactions of $\mathrm{Cl}^{4 \mathrm{a}}$ and $\mathrm{OH}^{4 \mathrm{~b}}$ radicals with ketene have appeared, and there have been experimental studies of ketene reactions with $\left(\mathrm{CF}_{3}\right)_{2} \mathrm{NO} \cdot,{ }^{4 \mathrm{c}} \mathrm{NO} \cdot,{ }^{4 \mathrm{~d}} \mathrm{NO}_{2} \cdot{ }^{4 \mathrm{~d}}$ and $\mathrm{NO}_{3}{ }^{4 \mathrm{e}}$.
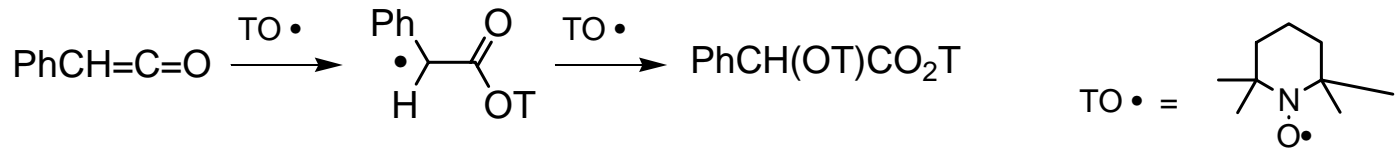

4

\section{Scheme 2}

The question remained whether ketene itself or [dimethyl(phenyl)silyl]ketene (12), which is even less reactive than ketene towards $\mathrm{H}_{2} \mathrm{O}$, would react with TEMPO. In 1936, Hurd and Williams ${ }^{4 \mathrm{f}}$ reported that reaction of $\mathrm{Ph}_{3} \mathrm{C} \cdot$ with $\mathrm{CH}_{2}=\mathrm{C}=\mathrm{O}$ was not observed. We now report computations at higher levels, including transition structures, and experimental studies of radical reactions of the relatively unreactive substrates ketene (1) and dimethyl(phenyl)silyl]ketene (12).

\section{Results}

Computations of the reactions of $\mathrm{CH}_{2}=\mathrm{C}=\mathrm{O}$ (1) with $\mathrm{H}_{2} \mathrm{NO}$ - for addition at 1-C and at 2-C forming the respective transition structures $\mathbf{2}_{\mathrm{TS}}$ and $\mathbf{3}_{\mathrm{TS}}$ and products $\mathbf{2}$ and $\mathbf{3}$, were carried out at the B3LYP/6-31G*//B3LYP/6-31G*, B3LYP/6-311G**//B3LYP/6-311G**, and B3LYP/6- 
311++G**//B3LYP/6-311++G** levels, including zero point vibrational energies. The results are given in Table 1 and summarized in Scheme 3, and show that in agreement with our preliminary studies $^{3 \mathrm{~b}}$ that addition at $1-\mathrm{C}$ is exothermic, and addition at 2-C is endothermic at all levels. Addition at $1-\mathrm{C}$ is more favorable than addition at $2-\mathrm{C}$ by $25.0,23.8$, and $23.1 \mathrm{kcal} / \mathrm{mol}$, respectively, at increasingly higher levels, and additions at both positions are predicted to become less favorable at the higher levels. The transition structure $\mathbf{2}_{\mathrm{Ts}}$ for attack at 1-C is 20.3 , 20.3, and $19.2 \mathrm{kcal} / \mathrm{mol}$ lower in energy than $\mathbf{3}_{\text {Ts }}$ for attack at $2-\mathrm{C}$ at increasingly higher levels, respectively. There are significant changes in the energies at different levels, but the energy differences are remarkably constant.

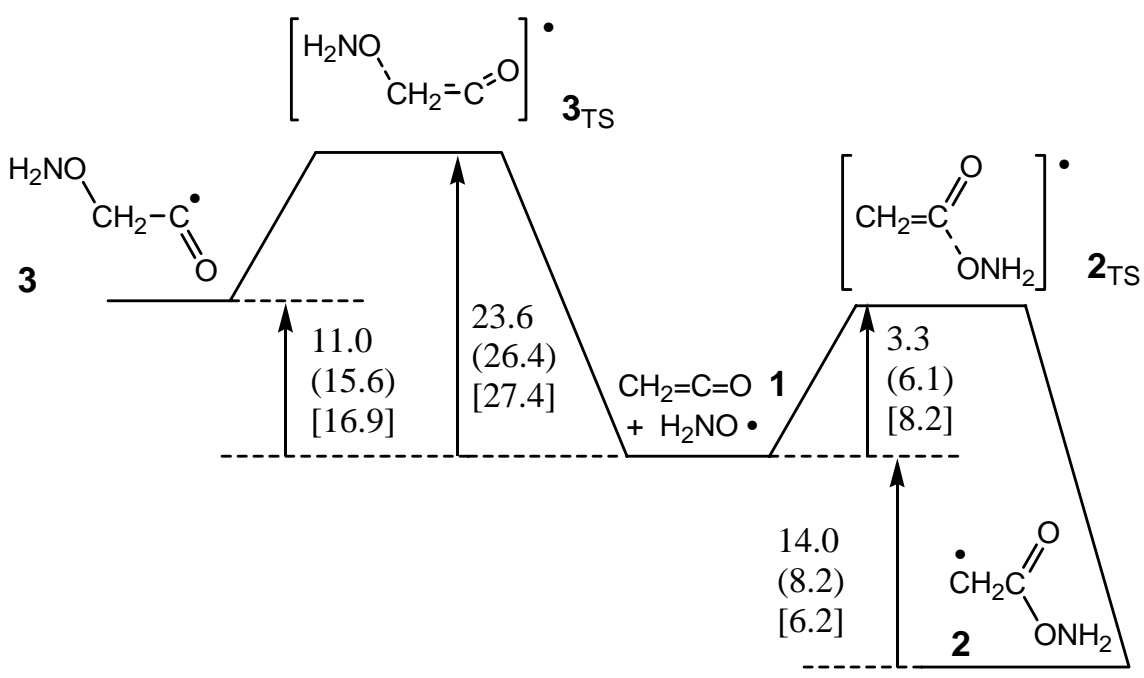

Scheme 3. Energy changes (kcal/mol) for $\mathrm{H}_{2} \mathrm{NO}$ - addition to ketene at B3LYP/6-31G*, B3L YP/6-311G** (parentheses), and B3LYP/6-311++G** [brackets].

Computations for TEMPO addition to $\mathrm{CH}_{2}=\mathrm{C}=\mathrm{O}$ were carried out at the B3LYP/631G*//B3LYP/6-31G* and B3LYP/6-311++G**//B3LYP/6-311++G** levels, and the results are presented in Table 1 and summarized in Scheme 4. These show that addition to 2-C forming $\mathrm{TOCH}_{2} \mathrm{C}(\cdot)=\mathrm{O}$ is less favorable than addition of $\mathrm{H}_{2} \mathrm{NO} \bullet$ at the same levels, by 5.8 and 6.6 $\mathrm{kcal} / \mathrm{mol}$, respectively, while addition at 1-C forming $\cdot \mathrm{CH}_{2} \mathrm{CO}_{2} \mathrm{~T}$ is less favorable by 11.2 and $11.0 \mathrm{kcal} / \mathrm{mol}$, respectively (Scheme 4). Thus $1-\mathrm{C}$ addition is favored by 18.5 and $18.8 \mathrm{kcal} / \mathrm{mol}$ at the two levels, respectively, or slightly less than found for addition of $\mathrm{H}_{2} \mathrm{NO}$.

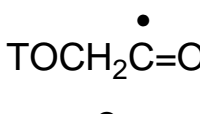

6
$\Delta E=16.8[23.6]$

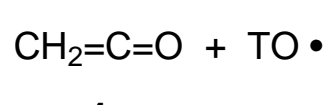

1

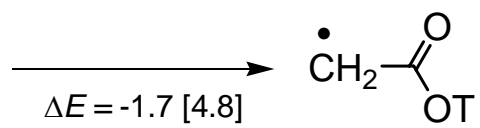

5

Scheme 4. Energy changes (kcal/mol) for TEMPO (TO•) addition at B3LYP/6-31G* and B3LYP/6-311++G** [brackets]. 
Reaction of $\mathrm{H}_{3} \mathrm{SiCH}=\mathrm{C}=\mathrm{O}$ with $\mathrm{H}_{2} \mathrm{NO}$ - was studied at the B3LYP/6-311++G**//B3LYP$311++\mathrm{G}^{* *}$ level, and it was found that addition to 2-C forming $\mathrm{H}_{2} \mathrm{NOCH}\left(\mathrm{SiH}_{3}\right) \mathrm{C}(\bullet)=\mathrm{O}$ is endothermic by $26.2 \mathrm{kcal} / \mathrm{mol}$, while addition at 1-C forming $\cdot \mathrm{CH}_{2} \mathrm{CO}_{2} \mathrm{NH}_{2}$ is endothermic by $8.5 \mathrm{kcal} / \mathrm{mol}$ (Scheme 5). Thus 1-C addition is favored by $17.7 \mathrm{kcal} / \mathrm{mol}$, which is $5.5 \mathrm{kcal} / \mathrm{mol}$ less than the difference of $23.2 \mathrm{kcal} / \mathrm{mol}$ found for addition to $\mathrm{CH}_{2}=\mathrm{C}=\mathrm{O}(\mathbf{1})$ at the same level (Scheme 1). Addition to $\mathrm{H}_{3} \mathrm{SiCH}=\mathrm{C}=\mathrm{O}$ is less favorable compared to $\mathrm{CH}_{2}=\mathrm{C}=\mathrm{O}$ (1) at 1-C by $9.2 \mathrm{kcal} / \mathrm{mol}$, and by $14.7 \mathrm{kcal} / \mathrm{mol}$ at $1-\mathrm{C}$.

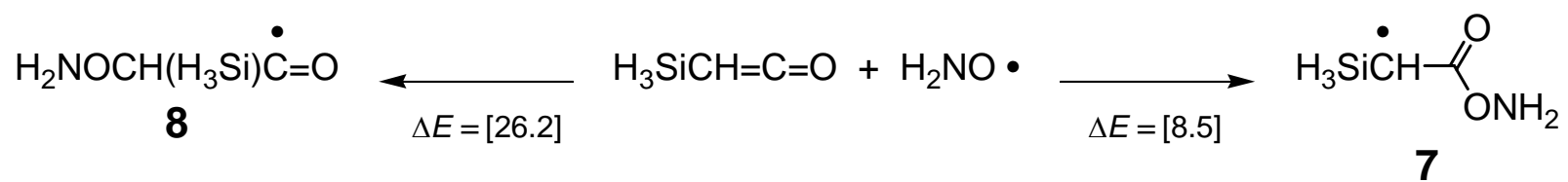

Scheme 5. Energy changes $(\mathrm{kcal} / \mathrm{mol})$ for $\mathrm{H}_{2} \mathrm{NO}$ - addition to $\mathrm{H}_{3} \mathrm{SiCH}=\mathrm{C}=\mathrm{O}$ at $\mathrm{B} 3 \mathrm{LYP} / 6$ $311++\mathrm{G}^{* *}$ [brackets].

In experimental studies we find acetyl chloride generates ketene over time when reacted with 1,8-bis(dimethylamino)naphthalene (9) with a catalytic amount of triethylamine in toluene at 65 ${ }^{\circ} \mathrm{C}$ by the procedure of Lectka, et al. ${ }^{5 a}$ as observed in situ by the IR absorption at $2135 \mathrm{~cm}^{-1}$. When the reaction was carried out in the presence of TEMPO the adduct $\mathbf{1 0}$ was isolated in low yield (Scheme 6). For kinetic studies ketene (1) was prepared by pyrolysis $\left(550^{\circ} \mathrm{C}\right)$ of diketene, ${ }^{5 b}$ and a stock solution in hexane was added to TEMPO in isooctane, and the decrease in the absorption of the ketene band was monitored at $2139 \mathrm{~cm}^{-1}$. Rate constants for the reaction of ketene (1) at $25{ }^{\circ} \mathrm{C}$ (Table 2) were measured over a concentration range of TEMPO from 0.280 to $0.971 \mathrm{M}$, and gave a linear correlation $k(\mathrm{obs})=(7.62 \pm 0.66) \times 10^{-5} \mathrm{M}^{-1} \mathrm{~s}^{-1}-(1.54 \pm 0.44) \mathrm{s}^{-1}$.

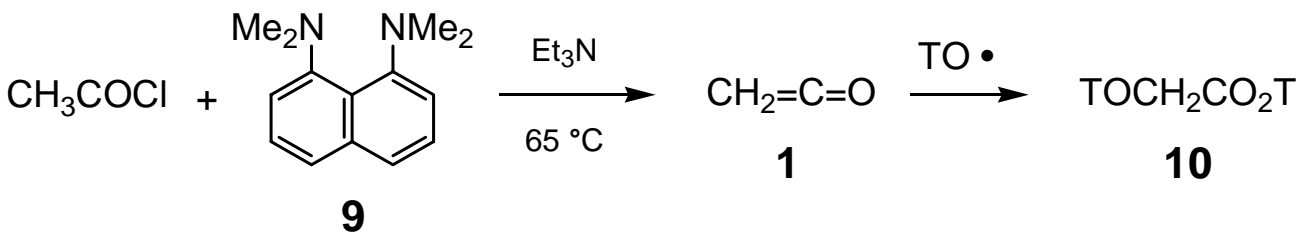

\section{Scheme 6}

Pyrolysis of alkyne $\mathbf{1 1}$ in a gas chromatograph gave dimethyl(phenyl)silyl]ketene (12) (Scheme 7). ${ }^{5 \mathrm{c}}$ Heating $\mathbf{1 2}$ in hexane with 6 equiv. of TEMPO gave a product mixture estimated by ${ }^{1} \mathrm{H}$ NMR to contain unreacted 12 and TEMPO adduct 13 in a 3:4 ratio, and possibly $\mathrm{PhMe}_{2} \mathrm{SiCHCO}_{2} \mathrm{H}$ (14). Column chromatography gave 13 in a $47 \%$ yield based on consumption of $\mathbf{1 2}$. The product $\mathbf{1 3}$ from addition of TEMPO was identified by its spectral properties, including the ${ }^{1} \mathrm{H}$ NMR which showed the 2 diastereotopic methyl groups attached to silicon as very sharp singlets at $\delta 0.50$ and 0.52 , and all eight methyl groups of the piperidinyl moieties as singlets. Careful examination of the product mixture showed only traces of $\mathrm{TOCH}_{2} \mathrm{CO}_{2} \mathrm{~T}(\mathbf{1 0})$. 
Rate constants for reaction of dimethyl(phenyl)silyl]ketene (12) with TEMPO at $92.1{ }^{\circ} \mathrm{C}$ were measured over a range of TEMPO concentration of 0.40 to $1.20 \mathrm{M}$, and gave a linear correlation $k(\mathrm{obs})=(4.41 \pm 0.35) \times 10^{-5} \mathrm{M}^{-1} \mathrm{~s}^{-1}-(0.39 \pm 0.29) \times 10^{-5} \mathrm{~s}^{-1}$. To estimate a rate constant for 12 at $25{ }^{\circ} \mathrm{C}$ the same temperature dependence of the reactivity as found for the bisketene $14^{3 \mathrm{~h}}$ (Table 2) was assumed to apply, and this gave a rate constant for 12 of $4.9 \times 10^{-7} \mathrm{M}^{-1} \mathrm{~s}^{-1}$.

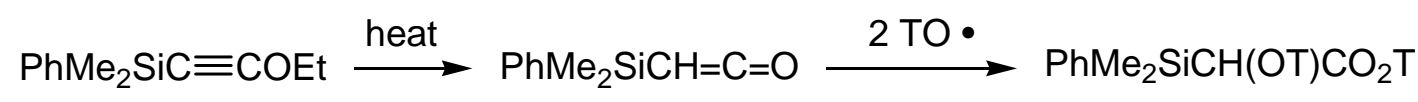

11

12

13

\section{Scheme 7}

The experimental range that could be studied for $\mathbf{1}$ and $\mathbf{1 2}$ was limited by the low reactivity of both substrates and the volatility of ketene, and so data over a wider range of concentrations of TEMPO and at different temperatures was not obtained. A hint of possible curvature could be inferred in the plots of $k$ (obs) vs [TEMPO], but until better experimental techniques are devised the present data will suffice for comparative purposes.

\section{Discussion}

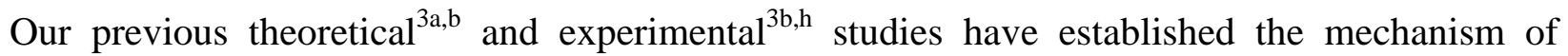
TEMPO reaction with ketenes as involving initial in-plane radical attack on the carbonyl carbon forming acyl substituted radical intermediates, followed by attack of a second TEMPO forming the product (Scheme 2). The large accelerations on the rate of TEMPO attack by radical stabilizing aryl, vinyl, and alkynyl substituents (Table 2) confirm that this first step of attack on $1-\mathrm{C}$ is rate limiting. The computational results and the occurrence of allylic and other rearrangements of the intermediate radicals in certain examples confirm attack on the carbonyl carbon is the first step. Simple acyl substituted radicals are known to have spin density predominantly on 2-C. ${ }^{3 a}$

The new computational studies confirm our previous conclusion ${ }^{3 b}$ that attack of $\mathrm{H}_{2} \mathrm{NO}$ - at 1$\mathrm{C}$ of ketene is predicted to be favored, while attack at 2-C is strongly endothermic, and is more than $20 \mathrm{kcal} / \mathrm{mol}$ less favorable than attack at 1-C (Scheme 3). The barrier for attack at 1-C is also much lower than for attack at 2-C. Addition to either position is indicated to become progressively less favorable at higher levels, but the preference for attack at 1-C is large at all levels. This preference parallels that found previously for reaction of ketene with $\mathrm{H}_{2} \mathrm{~N} \bullet, \mathrm{HO} \bullet, \mathrm{F} \bullet$, and $\mathrm{Cl} \bullet$, a result that was attributed to the high conjugative stability of the amide, carboxylic acid, and acyl halide systems formed. ${ }^{3 a}$ Addition of TEMPO to $\mathrm{CH}_{2}=\mathrm{C}=\mathrm{O}$ (1) is predicted to be less favorable than for $\mathrm{H}_{2} \mathrm{NO} \cdot$, but attack at 1-C is still strongly preferred. 
Rate constants for the reactions of ketenes with TEMPO and with water are collected in Table 2. Ketene (1) is found to be much less reactive than the ketenes 15a-d,f,g (Table 2), all of which possess conjugating substituents which are expected to stabilize an intermediate from TEMPO addition to 1-C, which would have radical character on 2-C, as shown for $\mathbf{4}$ (Scheme 2). Ketene is also less reactive by a factor of 39 towards TEMPO than is cyclopentylidenemethanone 16, in which the radical intermediate is stabilized by two alkyl groups. Also included in Table 2 are 3-pyridylketene $(\mathbf{1 5 g})^{2 \mathrm{e}}$ and the fulvenones $\mathbf{1 7}^{3 \mathrm{f}}$.

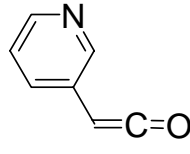

$15 \mathrm{~g}$

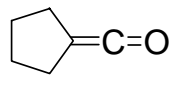

16

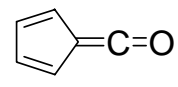

$17 a$

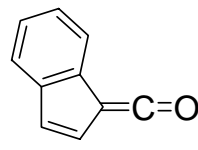

$17 b$

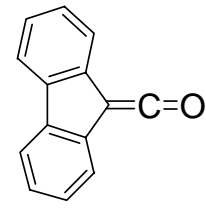

$17 \mathrm{c}$

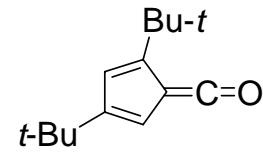

$17 d$

Dimethyl(phenyl)silyl]ketene (12) is even less reactive than ketene (1) towards TEMPO, by a factor of $1.6 \times 10^{3}$. This is in agreement with the computational results, in which the reaction of $\mathrm{H}_{3} \mathrm{SiCH}=\mathrm{C}=\mathrm{O}$ with $\mathrm{H}_{2} \mathrm{NO} \cdot$ at $1-\mathrm{C}$ is predicted to be less favorable than for $\mathrm{CH}_{2}=\mathrm{C}=\mathrm{O}$ by 14.7 $\mathrm{kcal} / \mathrm{mol}$ (Table 1 ). The low reactivity of $\mathbf{1 2}$ may be attributed to the ground state stabilization of this ketene by the $\beta$-silicon effect, which is the favorable in-plane interaction of the C-Si bond with the electron deficient carbonyl group. This stabilization is lost in the intermediate $\mathbf{7}$ from addition of the aminoxyl radical at 1-C. The decrease in the stabilization of the intermediate radical due to the $\mathrm{SiH}_{3}$ substituent is predicted to be $9.2 \mathrm{kcal} / \mathrm{mol}$ for addition at 2-C, compared to $14.7 \mathrm{kcal} / \mathrm{mol}$ for addition at $1-\mathrm{C}$, and this difference of $5.5 \mathrm{kcal} / \mathrm{mol}$ is indicative of the stabilization of the radical 8 formed by addition at 2-C by the $\beta$-silicon effect.

The computations at the B3LYP/6-311++G**//B3LYP/6-311++G** level predict that the additions at 1-C of TEMPO to $\mathrm{CH}_{2}=\mathrm{C}=\mathrm{O}$ (1) (Scheme 4) and of $\mathrm{H}_{2} \mathrm{NO} \cdot$ to $\mathrm{H}_{3} \mathrm{SiCH}=\mathrm{C}=\mathrm{O}$ (Scheme 5) will be endothermic, by 4.8 and $8.5 \mathrm{kcal} / \mathrm{mol}$, respectively. While these predictions may not be accurate for the solution phase reactions (Schemes 6, 7) such endothermic steps are not unreasonable, because addition of the second TEMPO as in Scheme 2 will occur at a near diffusion controlled rate, and so the initial attack would still be rate limiting.

The fit of the second order rate constants for the reactions of ketenes with TEMPO with the rate constants for hydration of the same ketenes (Table 2) gives the correlation of eq. 2 as illustrated in Figure 1. A qualitative correlation is observed, $r=0.94$, and such a correlation between a free radical and a polar reaction is perhaps surprising. However in both cases in-plane attack by oxygen on the carbonyl carbon of the ketene is involved, and the oxygen of nitroxyl radicals is often considered as being nucleophilic, and possessing some negative charge. ${ }^{\text {7a }}$ The $\mathrm{p} K_{\mathrm{a}}$ of TEMPO has been estimated as $-5.5 \pm 1,{ }^{7 \mathrm{~b}}$ indicating the nitroxyl is about $3 \mathrm{p} K_{\mathrm{a}}$ units less basic than $\mathrm{CH}_{3} \mathrm{OH}$.

$$
\log k_{2}(\text { TEMPO })=1.18 \log k\left(\mathrm{H}_{2} \mathrm{O}\right)-4.39
$$


The range in reactivity of the TEMPO reactions is $10^{9}$, as compared to $9 \times 10^{6}$ for the $\mathrm{H}_{2} \mathrm{O}$ reactions. A variety of effects might be involved to different degrees in these reactions, including steric effects of the bulky tetramethylpiperidinyl moiety, solvation effects, and aromaticity in the fulvenones. However the overall correlation shows somewhat surprisingly that despite the differences there is a reasonable correlation of the reactivities. Presumably the stabilities of the reactants play an important role, and the energetic changes in going to the transition states are similar.

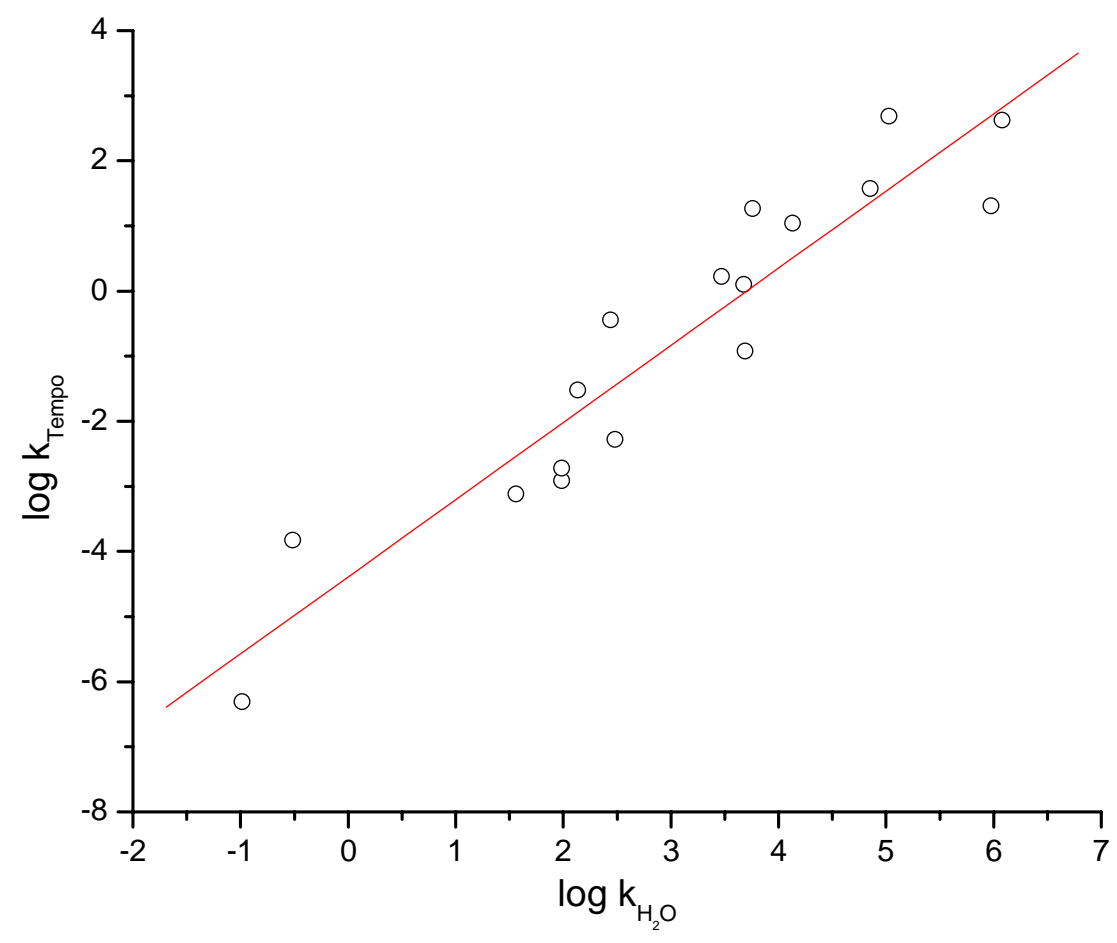

Figure 1. Correlation of rate constants $k_{2}$ for ketene reactions with TEMPO with rate constants for hydration.

\section{Conclusions}

In conclusion computational studies predict a strong preference for reactions of aminoxyl radicals with ketene at 1-C as compared to addition to 2-C, a preference that may be explained as due to the formation the stabilized ester function. Computations on $\mathrm{H}_{3} \mathrm{SiCH}=\mathrm{C}=\mathrm{O}$ indicate this ketene will be less reactive than $\mathrm{CH}_{2}=\mathrm{C}=\mathrm{O}(\mathbf{1})$, as expected from the strong ground state stabilization of the reactant due to the $\beta$-silicon effect. Experimental studies of TEMPO reactions with $\mathrm{CH}_{2}=\mathrm{C}=\mathrm{O}$ (1) and $\mathrm{Me}_{3} \mathrm{SiCH}=\mathrm{C}=\mathrm{O}$ agree with the computational predictions, and the rate 
constants for the reactions of 17 ketenes with TEMPO give a surprisingly good correlation with the rate constants for reaction of the same ketenes with $\mathrm{H}_{2} \mathrm{O}$.

Table 1. Energies (Hartrees) for aminoxyl radical addition to ketene (1) and $\mathrm{H}_{3} \mathrm{SiCH}=\mathrm{C}=\mathrm{O}^{a}$

\begin{tabular}{|c|c|c|c|c|c|}
\hline Structure & Level & E & $\mathrm{ZPVE}^{\mathrm{c}}$ & $E+\mathrm{ZPVE}$ & $\begin{array}{c}E \text { (rel) } \\
{[\mathrm{kcal} /} \\
\mathrm{mol}]\end{array}$ \\
\hline $\mathrm{H}_{2} \mathrm{NO} \bullet$ & B3LYP/6-31G*b & -131.082450 & 0.025808 & -131.056642 & \\
\hline $\mathrm{CH}_{2}=\mathrm{C}=\mathrm{O}$ & & -152.598470 & 0.031747 & -152.566723 & \\
\hline$\left[\mathrm{H}_{2} \mathrm{NO}-\mathrm{CH}_{2}=\mathrm{C}=\mathrm{O}\right] \cdot(\mathrm{TS})$ & & -283.647947 & 0.062191 & -283.585756 & 23.6 \\
\hline $\mathrm{H}_{2} \mathrm{NOCH}_{2} \mathrm{C}(\cdot)=\mathrm{O}$ & & -283.671200 & 0.065364 & -283.605836 & 11.0 \\
\hline$\left[\mathrm{CH}_{2}=\mathrm{C}\left(--\mathrm{ONH}_{2}\right)=\mathrm{O}\right] \cdot(\mathrm{TS})$ & & -283.681099 & 0.062962 & -283.618137 & 3.3 \\
\hline - $\mathrm{CH}_{2} \mathrm{CO}_{2} \mathrm{NH}_{2}$ & & -283.710760 & 0.065066 & -283.645694 & -14.0 \\
\hline $\mathrm{H}_{2} \mathrm{NO} \bullet$ & B3LYP/6-311G**b & -131.129766 & 0.026428 & -131.103338 & \\
\hline $\mathrm{CH}_{2}=\mathrm{C}=\mathrm{O}$ & & -152.647753 & 0.031577 & -152.616176 & \\
\hline$\left[\mathrm{H}_{2} \mathrm{NO}--\mathrm{CH}_{2}=\mathrm{C}=\mathrm{O}\right] \cdot(\mathrm{TS})$ & & -283.739301 & 0.061888 & -283.677413 & 26.4 \\
\hline $\mathrm{H}_{2} \mathrm{NOCH}_{2} \mathrm{C}(\cdot)=\mathrm{O}$ & & -283.759077 & 0.064443 & -283.694634 & 15.6 \\
\hline$\left[\mathrm{CH}_{2}=\mathrm{C}\left(-\mathrm{ONH}_{2}\right)=\mathrm{O}\right] \cdot(\mathrm{TS})$ & & -283.772393 & 0.062569 & -283.709824 & 6.1 \\
\hline$\cdot \mathrm{CH}_{2} \mathrm{CO}_{2} \mathrm{NH}_{2}$ & & -283.797270 & 0.064620 & -283.732650 & -8.2 \\
\hline $\mathrm{H}_{2} \mathrm{NO} \bullet$ & B3LYP/6-311++G** & -131.138719 & 0.025982 & -131.112737 & \\
\hline $\mathrm{CH}_{2}=\mathrm{C}=\mathrm{O}$ & & -152.651599 & 0.031510 & -152.620089 & \\
\hline$\left[\mathrm{H}_{2} \mathrm{NO}-\mathrm{CH}_{2}=\mathrm{C}=\mathrm{O}\right] \cdot(\mathrm{TS})$ & & -283.750971 & 0.061883 & -283.689088 & 27.4 \\
\hline $\mathrm{H}_{2} \mathrm{NOCH}_{2} \mathrm{C}(\cdot)=\mathrm{O}$ & & -283.770160 & 0.064417 & -283.705743 & 17.0 \\
\hline$\left[\mathrm{CH}_{2}=\mathrm{C}\left(--\mathrm{ONH}_{2}\right)=\mathrm{O}\right] \cdot(\mathrm{TS})$ & & -283.782118 & 0.062359 & -283.719759 & 8.2 \\
\hline - $\mathrm{CH}_{2} \mathrm{CO}_{2} \mathrm{NH}_{2}$ & & -283.807236 & 0.064542 & -283.742694 & -6.2 \\
\hline TO• & B3LYP/6-31G* & -483.719770 & 0.263498 & -483.456272 & \\
\hline $\mathrm{CH}_{2}=\mathrm{C}=\mathrm{O}$ & & -152.598471 & 0.031745 & -152.566726 & \\
\hline $\mathrm{TOCH}_{2} \mathrm{C}(\cdot)=\mathrm{O}$ & & -636.296871 & 0.300651 & -635.996220 & 16.8 \\
\hline$\cdot \mathrm{CH}_{2} \mathrm{CO}_{2} \mathrm{~T}$ & & -636.324928 & 0.299170 & -636.025758 & -1.7 \\
\hline TO• & B3LYP/6-311++G** & -483.855969 & 0.260681 & -483.595288 & \\
\hline $\mathrm{CH}_{2}=\mathrm{C}=\mathrm{O}$ & & -152.651598 & 0.031510 & -152.620088 & \\
\hline $\mathrm{TOCH}_{2} \mathrm{C}(\cdot)=\mathrm{O}$ & & -636.474174 & 0.296329 & -636.177845 & 23.6 \\
\hline$\cdot \mathrm{CH}_{2} \mathrm{CO}_{2} \mathrm{~T}$ & & -636.502428 & 0.294705 & -636.207723 & 4.8 \\
\hline $\mathrm{H}_{3} \mathrm{SiCH}=\mathrm{C}=\mathrm{O}$ & & -443.384353 & 0.048385 & -443.335968 & \\
\hline $\mathrm{H}_{2} \mathrm{NOCH}\left(\mathrm{SiH}_{3}\right) \mathrm{C}(\cdot)=\mathrm{O}$ & & -574.486280 & 0.079348 & -574.406932 & 26.2 \\
\hline - $\mathrm{CH}\left(\mathrm{SiH}_{3}\right) \mathrm{CO}_{2} \mathrm{NH}_{2}$ & & -574.514680 & 0.079479 & -574.435201 & 8.5 \\
\hline
\end{tabular}

${ }^{a}$ Using Gaussian 98 unless indicated. ${ }^{b}$ Using Gaussian 94. ${ }^{c}$ Zero point vibrational energy. 
Table 2. Rate constants for the reaction of ketenes with TEMPO and with $\mathrm{H}_{2} \mathrm{O}$ at $25{ }^{\circ} \mathrm{C}$

\begin{tabular}{cccc}
\hline & $k_{2}(\mathrm{TEMPO})\left(\mathrm{M}^{-1} \mathrm{~s}^{-1}\right)$ & $k\left(\mathrm{H}_{2} \mathrm{O}\right)\left(\mathrm{s}^{-1}\right)$ & Ref. \\
\hline $\mathrm{CH}_{2}=\mathrm{C}=\mathrm{O}(\mathbf{1})$ & $7.61 \times 10^{-4}$ & 36.5 & this work \\
$\mathrm{PhMe}_{2} \mathrm{SiCH}=\mathrm{C}=\mathrm{O}(\mathbf{1 2})$ & $4.9 \times 10^{-7}$ & 0.139 & this work \\
$\left(\mathrm{Me}_{3} \mathrm{SiC}=\mathrm{C}=\mathrm{O}\right)_{2}(\mathbf{1 4})$ & $1.50 \times 10^{-4}$ & 0.307 & $3 \mathrm{~h}$ \\
$\mathrm{Ph}_{2} \mathrm{C}=\mathrm{C}=\mathrm{O}(\mathbf{1 5 a})$ & 0.357 & 275 & $3 \mathrm{~h}$ \\
$\mathrm{PhCH}=\mathrm{C}=\mathrm{O}(\mathbf{1 5 b})$ & 1.26 & $4.77 \times 10^{3}$ & $3 \mathrm{~h}$ \\
$(E)-\mathrm{PhCH}=\mathrm{CHCH}=\mathrm{C}=\mathrm{O}(\mathbf{1 5 c})$ & 18.4 & $7.16 \times 10^{3}$ & $3 \mathrm{~h}$ \\
$\mathrm{PhC} \equiv \mathrm{CCH}=\mathrm{C}=\mathrm{O}(\mathbf{1 5 d})$ & 37.2 & 96.6 & $3 \mathrm{~h}$ \\
$n-\mathrm{BuCH}=\mathrm{C}=\mathrm{O}(\mathbf{1 5 e})$ & $1.22 \times 10^{-3}$ & $2.95 \times 10^{3}$ & $3 \mathrm{~h}$ \\
1-(Naphthyl)CH=C=O (15f) & 1.68 & $3.36 \times 10^{4}$ & $3 \mathrm{~h}$ \\
3-Pyridylketene (15g) & 11.0 & 304 & $3 \mathrm{~g}$ \\
$\mathrm{CyclopropylCH}=\mathrm{C}=\mathrm{O}(\mathbf{1 5 h})$ & $5.26 \times 10^{-3}$ & 96.6 & $3 \mathrm{~g}$ \\
$\mathrm{CH} \mathrm{H}_{2}=\mathrm{CH}(\mathrm{CH})_{3} \mathrm{CH}=\mathrm{C}=\mathrm{O}(\mathbf{1 5 i})$ & $1.89 \times 10^{-3}$ & 230 & $3 \mathrm{~h}$ \\
Cyclopentylideneketene (16) & $2.98 \times 10^{-2}$ & $9.00 \times 10^{5}$ & $3 \mathrm{f}$ \\
Pentafulvenone (17a) & 20.2 & $1.20 \times 10^{6}$ & $3 \mathrm{f}$ \\
Indenylideneketene (17b) & 422 & $1.07 \times 10^{5}$ & $3 \mathrm{f}$ \\
Fluorenylideneketene (17c) & 482 & $4.91 \times 10^{3}$ & $3 \mathrm{f}$ \\
\hline 2,4-Di-(t-Bu)pentafulvenone (17d) & 0.120 & &
\end{tabular}

\section{Experimental Section}

General Procedures. Reactions were conducted in dried glassware under an atmosphere of $\mathrm{N}_{2}$ or Ar. Chromatography was carried out on silica gel. Triethylamine was dried by distillation from $\mathrm{CaH}_{2}$, and $\mathrm{Ar}$ was bubbled through solutions for dehydrochlorinations for $1 \mathrm{~h}$ at the beginning of these reactions. Toluene was distilled from Na containing benzophenone. Solutions for TEMPO reactions were degassed with Ar.

Computations. Computations were carried out using Gaussian 94 with a Silicon Graphics Indigo computer and Gaussian 98 with a computer cluster from Velocet Communications, Toronto. Final energies include ZPVE, in contrast to those reported previously. ${ }^{3 b}$

TEMPO Addition to ketene (1) forming 2,2,6,6-tetramethyl-1-[2-oxo-2-[(2,2,6,6-tetramethylpiperidin-1-yl)oxy]ethoxy]piperidine (10). TEMPO (520 mg, $3.3 \mathrm{mmol}$ ), 1,8bis(dimethylamino)naphthalene ( $370 \mathrm{mg}, 1.7 \mathrm{mmol})$, and $\mathrm{Et}_{3} \mathrm{~N}(0.04 \mathrm{~mL}, 0.3 \mathrm{mmol})$ were added to a cooled solution of acetyl chloride $(0.1 \mathrm{~mL}, 1.4 \mathrm{mmol})$ in $3 \mathrm{~mL}$ of toluene in a $25 \mathrm{~mL}$ round bottom flask. The solution was heated at $65^{\circ} \mathrm{C}$ for $9 \mathrm{~h}$, cooled and filtered, and the filtrate was extracted with $1 \mathrm{~N} \mathrm{HCl}$ and then with $\mathrm{NaCl}$ solution. The organic layer was dried and 
concentrated, and chromatography $\left(\mathrm{SiO}_{2}\right.$, EtOAc/hexane 1:4) gave pure 10 (12 mg, $0.033 \mathrm{mmol}$, 2\%), and in later fractions $8 \%$ of $\mathbf{1 0}$ containing some TEMPO. Pure oil $\mathbf{1 0}$ gave ${ }^{1} \mathrm{H}$ NMR (300 $\mathrm{MHz}, \mathrm{CDCl}_{3}$ ): $\delta 1.09$ (s, $\left.6 \mathrm{H}, 2 \mathrm{CH}_{3}\right), 1.1-1.7\left(\mathrm{~m}, 12 \mathrm{H}, 6 \mathrm{CH}_{2}\right), 1.17\left(\mathrm{~s}, 6 \mathrm{H}, 2 \mathrm{CH}_{3}\right), 1.19(\mathrm{~s}, 6 \mathrm{H}$, $\left.2 \mathrm{CH}_{3}\right), 1.20$ (s, $\left.6 \mathrm{H}, 2 \mathrm{CH}_{3}\right), 4.51$ (s, $\left.2 \mathrm{H}, \mathrm{CH}_{2} \mathrm{OT}\right) .{ }^{13} \mathrm{C} \mathrm{NMR}\left(100 \mathrm{MHz}, \mathrm{CDCl}_{3}\right): \delta 17.17,17.21$, 20.2, 20.8, 29.9, 32.2, 33.0, 39.2, 39.8, 60.3, 60.4, 75.1 (C=O not observed). IR ( $\mathrm{CDCl}_{3}$ ): $\tilde{v}$ 1750, $1773 \mathrm{~cm}^{-1}$. EIMS (70 eV): m/z $354\left(0.1 \mathrm{M}^{+}\right), 198\left(100, \mathrm{M}^{+}-\mathrm{TO}\right), 156$ (31, TO $), 140$ (99, $\mathrm{T}^{+}$). HR-EIMS: Calcd for $\mathrm{C}_{20} \mathrm{H}_{38} \mathrm{~N}_{2} \mathrm{O}_{3}$ 354.2882, obs. 354.2872.

TEMPO Addition to phenyldimethylsilylketene (12) forming 1-[1-[dimethyl(phenyl)silyl]-2oxo-2-[(2,2,6,6-tetramethylpiperidin-1-yl)oxy]ethoxy]-2,2,6,6-tetramethylpiperidine (13).

Ketene $12^{5 \mathrm{c}}$ (27 mg, $0.15 \mathrm{mmol}$ ) and TEMPO (146 mg, $0.94 \mathrm{mmol}$ ) in $0.5 \mathrm{~mL}$ of hexanes in a sealed tube was heated at $75{ }^{\circ} \mathrm{C}$ for $20 \mathrm{~h}$. The solvent was evaporated, and examination by ${ }^{1} \mathrm{H}$ NMR showed the presence of $\mathbf{1 3}$ and unreacted $\mathbf{1 2}$ in a 4:3 ratio, and possibly $\mathrm{PhMe}_{2} \mathrm{SiCH}_{2} \mathrm{CO}_{2} \mathrm{H}$. Chromatography $\left(\mathrm{SiO}_{2}\right.$, EtOAc/hexane 1:9) gave first $24 \mathrm{mg}$ of almost pure material and then a fraction of pure oil $13(21 \mathrm{mg}, 0.043 \mathrm{mmol}, 29 \%) .{ }^{1} \mathrm{H} \mathrm{NMR} 300 \mathrm{MHz}$, $\left.\mathrm{CDCl}_{3}\right) \delta 0.50$ (s, 3H, $\mathrm{CH}_{3} \mathrm{Si}$ ), 0.52 (s, 3H, $\mathrm{CH}_{3} \mathrm{Si}$ ), 0.54 (s, 3H, $\mathrm{CH}_{3}$ ), 0.85 (s, 3H, $\mathrm{CH}_{3}$ ), 1.04 (s, $\left.3 \mathrm{H}, \mathrm{CH}_{3}\right), 1.07$ (s, 3H, $\mathrm{CH}_{3}$ ), 1.14 (s, 3H, $\left.\mathrm{CH}_{3}\right), 1.16$ (s, 3H, $\mathrm{CH}_{3}$ ), 1.25 (s, 3H, $\left.\mathrm{CH}_{3}\right), 1.33$ (s, 3H, $\mathrm{CH}_{3}$ ), 1.0-1.7 (m, 12, 6H, CH ${ }_{2}$ ), 4.74 (s, 1H, CHOT), 7.3-7.4 (m, 3H, Ph), 7.6-7.7 (m, 2H, Ph). ${ }^{13} \mathrm{C}$ NMR $\left.100 \mathrm{MHz}, \mathrm{CDCl}_{3}\right): \delta-5.3,-3.6,17.2,17.5,20.4,20.8,21.0,31.9,33.2,33.9,35.5$, 39.6, 40.8, 41.4, 59.5, 60.0, 60.2, 61.9, 77.9, 128.0, 129.8, 134.6, 135.8, 171.2. IR $\left(\mathrm{CDCl}_{3}\right): \tilde{v}$ $1760 \mathrm{~cm}^{-1}, 1772 \mathrm{~cm}^{-1}$. EIMS (70 eV): $\mathrm{m} / \mathrm{z} 488\left(0.02 \mathrm{M}^{+}\right), 332\left(19, \mathrm{M}^{+}-\mathrm{TO}\right), 176\left(8, \mathrm{M}^{+}-2 \mathrm{TO}\right)$, $161\left(63, \mathrm{M}^{+}-2 \mathrm{TO}, \mathrm{Me}\right), 140\left(100, \mathrm{~T}^{+}\right)$. HR-EIMS: Calcd for $\mathrm{C}_{28} \mathrm{H}_{47} \mathrm{~N}_{2} \mathrm{O}_{3} \mathrm{Si}$ 487.3356, obs. 487.3359.

Kinetics of TEMPO addition to ketene 1. Ketene (1) prepared by heating of diketene to $550{ }^{\circ} \mathrm{C}$ was condensed in hexane and stored at $-78{ }^{\circ} \mathrm{C}$. The solution showed the ketene IR band at $2139 \mathrm{~cm}^{-1}$ and based on the UV absorbance of 0.04 at $325 \mathrm{~nm}$ (reported $\left.\varepsilon=10\right)^{7}$ had a concentration of $0.5 \mathrm{M}$. An aliquot of this solution $(60 \mu \mathrm{L})$ was injected into a solution of freshly sublimed TEMPO in isooctane $(0.280$ to $0.971 \mathrm{M})$ and the decrease in the ketene absorption with time was monitored at $2139 \mathrm{~cm}^{-1}$.

Kinetics of TEMPO addition to phenyldimethylsilylketene (12). Aliquots (200 $\mu \mathrm{L})$ of solutions containing ketene $12\left(4 \mathrm{~mL}, 6.24 \times 10^{-3} \mathrm{M}\right)$ and freshly sublimed TEMPO (0.401 to $1.197 \mathrm{M}$ ) were sealed in glass ampoules and heated at $92.0{ }^{\circ} \mathrm{C}$. Samples were removed at intervals and the decrease in the ketene absorption with time at $2112 \mathrm{~cm}^{-1}$ was measured. These were fit to a first order rate expression and the derived rate constants gave a dependence on [TEMPO] $k($ obs $)=(4.41 \pm 0.35) \times 10^{-5} \mathrm{~s}^{-1} \mathrm{M}^{-1}$ [TEMPO] $-(3.89 \pm 2.94) \times 10^{-6} \mathrm{~s}^{-1}$. 


\section{Acknowledgements}

Financial support by the Natural Sciences and Engineering Research Council of Canada, The Petroleum Research Fund administered by the American Chemical Society, and the Canada Council for the Arts for a Killam Fellowship to T. T. T. is gratefully acknowledged.

\section{References}

1. (a) Allen, A. D.; Andraos, J.; Kresge, A. J.; McAllister, M. A.; Tidwell, T. T. J. Am. Chem. Soc. 1992, 114, 1878. (b) Zhao, D.; Allen, A. D.; Tidwell, T. T. J. Am. Chem. Soc. 1993, 115, 10097. (c) Andraos, J.; Kresge, A. J. J. Photochem. Photobiol. A: Chem. 1991, 57, 165. (d) Andraos, J.; Kresge, A. J. Can. J. Chem. 2000, 78, 508.

2. (a) Allen, A. D.; Tidwell, T. T. J. Org Chem. 1999, 64, 266. (b) Allen, A. D.; Moore, P. A.; Missiha, S.; Tidwell, T. T. J. Org. Chem. 1999, 64, 4690. (c) Sung, K.; Tidwell, T. T. J. Am. Chem. Soc. 1998, 120, 3043. (d) Wagner, B. D.; Arnold, B. R.; Brown, G. S.; Lusztyk, J. J. Am. Chem. Soc. 1998, 120, 1827. (e) Acton, A. W.; Allen, A. D.; Antunes, L. M.; Fedorov, A. V.; Najafian, K.; Tidwell, T. T.: Wagner, B. D. J. Am. Chem. Soc. 2002, 124, 13790.

3. (a) Sung, K.; Tidwell, T. T. J. Org. Chem. 1998, 63, 9690. (b) Huang, H.; Henry-Riyad, H.; Tidwell, T. T. J. Am. Chem. Soc. 1999, 121, 3939. (c) Allen, A. D.; Fenwick, M. H.; Jabri, A.; Rangwala, H.; Saidi, K.; Tidwell, T. T. Org. Lett. 2001, 3, 4095. (d) Carter, J.; Fenwick, M. F.; Huang, W.; Popik, V. V.; Tidwell, T. T. Can. J. Chem. 1999, 77, 80. (e) Tidwell, T. T.; Fenwick, M. H. Eur. J. Org. Chem. 2001, 3415. (f) Allen, A. D.; Porter, J.; Tahmassebi, D.; Tidwell, T. T. J. Org. Chem. 2001, 66, 7420. (g) Allen, A. D.; Fenwick, M. H.; HenryRiyad, H.; Tidwell, T. T. J. Org. Chem. 2001, 66, 5759. (h) Allen, A. D.; Cheng, B.; Fenwick, N. H.; Huang, W.; Missiha, S.; Tahmassebi, D.; Tidwell, T. T. Org. Lett. 1999, 1, 693.

4. (a) Hou, H.; Wang, B.; Gu, Y. J. Phys. Chem. A 2000, 104, 320. (b) Hou, H.; Wang, B.; Gu, Y. Phys. Chem. Chem. Phys. 2000, 2, 2329. (c) Banks, R. E.; Haszeldine, R. N.; Murray, M. B. J. Fluorine Chem. 1981, 17, 561. (d) Adam, W.; Bottle, S. E.; Grice, I. D.; Pfeiler, D.; Wentrup, C. Tetrahedron Lett. 1996, 37, 2113. (e) Seland, J. G.; Noremsaune, I. M. W.; Neilsen, C. J. J. Chem. Soc., Faraday Trans. 1996, 92, 3459. (f) Hurd, C. D.; Williams, J. W. J. Am. Chem. Soc. 1936, 58, 962.

5. (a) Taggi, A. E.; Hafez, A. M.; Wack, H.; Young, B.; Drury, W. J. III; Lectka, T. J. Am. Chem. Soc. 2000, 122, 7831. (b) Andreades, S.; Carlson, H. D. Org. Synth 1973, Coll. Vol. 5, 679. (c) Liu, R.; Marra, R. M.; Tidwell, T. T. J. Org. Chem. 1996, 61, 6227.

6. (a) Gaussian 94W, Revision E.1: Frisch, M. J.; Trucks, G. W.; Schlegel, H. B.; Gill, P. M. W.; Johnson, B. G.; Robb, M. A.; Cheeseman, J. R.; Keith, T.; Petersson, G. A.; Montgomery, J. A.; Raghavachari; K.; Al-Laham, M. A.; Zakrzewski, U. G.; Ortiz, J. V.; Foresman, J. B.; Cioslowski, J.; Stefanov, B. B.; Nanayakkara, A.; Challacombe, M.; Peng, 
C. Y.; Ayala, P. W.; Chen, W.; Wong, M. W.; Andres, J. L.; Replogle, E. S.; Gomperts, R.; Martin, R. L.; Fox, D. J.; Binkley, J. S.; Defrees, D. J.; Baker, J.; Stewart, J. P.; HeadGordon, J.; Gonzales, C.; Pople, J. A. Gaussian Inc., Pittsburgh, PA, 1995. (b) Gaussian 98, Revision A.9, Frisch; M. J.; Trucks, G. W.; Schlegel, H. B.; Scuseria, G. E.; Robb, M. A.; Cheeseman, J. R.; Zakrzewski, V. G.; Montgomery, J. A., Jr.; Stratmann, R. E.; Burant, J. C.; Dapprich, S.; Millam, J. M.; Daniels, A. D.; Kudin, K. N.; Strain, M. C.; Farkas, O.; Tomasi, J.; Barone, V.; Cossi, M.; Cammi, R.; Mennucci, B.; Pomelli, C.; Adamo, C.; Clifford, S.; Ochterski, J.; Petersson, G. A.; Ayala, P. Y.; Cui, Q.; Morokuma, K.; Malick, D. K.; Rabuck, A. D.; Raghavachari, K.; Foresman, J. B.; Cioslowski, J.; Ortiz, J. V.; Baboul, A. G.; Stefanov, B. B.; Liu, G.; Liashenko, A.; Piskorz, P.; Komaromi, I.; Gomperts, R.; Martin, R. L.; Fox, D. J.; Keith, T.; Al-Laham, M. A.; Peng, C. Y.; Nanayakkara, A.; Challacombe, M.; Gill, P. M. W.; Johnson, B.; Chen, W.; Wong, M. W.; Andres, J. L.; Gonzalez, C.; Head-Gordon, M.; Replogle, E. S.; Pople, J. A. Gaussian, Inc., Pittsburgh PA, 1998.

7. (a) Volodarsky, L. B.; Reznikov, V. A.; Ovcharenko, V. I. Synthetic Chemistry of Stable Nitroxides; CRC Press: Boca Raton, 1994. (b) Maletesta, V.; Ingold, K. U. J. Am. Chem. Soc. 1973, 95, 6404. 